\title{
Exogenous paraoxonase-1 during oocyte maturation improves bovine embryo development in vitro
}

\author{
JAA Rincón $^{1}$ | EM Madeira ${ }^{2}$ | FT Campos ${ }^{2}$ | B Mion $^{2}$ | JF Silva ${ }^{2}$ | VA Absalón- \\ Medina $^{3}$ | WR Butler ${ }^{4}$ | MN Corrêa ${ }^{1}$ | LMC Pegoraro $^{5}$ | A Schneider ${ }^{6}$
}

\author{
${ }^{1}$ Department of Veterinary \\ Clinics, Veterinary College, Universidade \\ Federal de Pelotas, Pelotas, Brazil \\ ${ }^{2}$ Department of Pathology, Veterinary \\ College, Universidade Federal de Pelotas, \\ Pelotas, Brazil \\ ${ }^{3}$ Department of Clinical Studies Section \\ of Reproduction and Behavior, School \\ of Veterinary Medicine, University of \\ Pennsylvania New Bolton Center, Kennett \\ Square, PA, USA \\ ${ }^{4}$ Department of Animal Science, College \\ of Agriculture and Life Sciences, Cornell \\ University, Ithaca, NY, USA \\ ${ }^{5}$ Empresa Brasileira de Pesquisa \\ Agropecuária (Embrapa) Clima Temperado, \\ Pelotas, Brazil \\ ${ }^{6}$ Department of Nutrition, College of \\ Nutrition, Universidade Federal de Pelotas, \\ Pelotas, Brazil
}

\section{Correspondence}

Augusto Schneider, Rua Gomes Carneiro, 1 Sala 239, CEP: 96010-610, College of Nutrition, Universidade Federal de Pelotas, Pelotas, RS, Brazil.

Email: augusto.schneider@ufpel.edu.br

\section{Contents}

Paraoxonase-1 (PON1) is an enzyme found in serum and follicular fluid that protects cell membrane and circulating lipids against oxidative damage. The aims of this study were to measure the direct effects of recombinant PON1 (rPON1) on bovine oocyte maturation at the molecular level (gene expression) and to measure the carry-over effects of PON1 on pre-implantation embryo development in vitro. COCs were submitted to IVM with the addition of $0.0,0.02,0.04$ and $0.08 \mathrm{mg} \mathrm{ml}^{-1}$ of rPON1, corresponding to an average PON1 arylesterase enzyme activity of $2.2 \pm 0.4,15.5 \pm 1.5$, $30.2 \pm 3.0$ and $57.9 \pm 5.0 \mathrm{U} \mathrm{ml}^{-1}$, respectively. The results indicated that addition of rPON1 during IVM improved embryo development in a dose-dependent manner as D7 embryo development was $22.2 \%, 29.4 \%, 32.2 \%$ and $37.0 \%$ for the treatment groups, respectively $(p=0.02)$. In conclusion, addition of PON1 enzyme during IVM exerted dose-related positive effects on embryo development rates to blastocysts.

\section{1 | INTRODUCTION}

The paraoxonase gene family includes three enzymes with antioxidant activity, of which paraoxonase-1 (PON1) is the most studied and synthesized mainly by the liver (Ferré et al., 2002). Once released into the bloodstream, it forms part of a complex along with high-density lipoproteins (HDL) and apoliprotein A I (ApoAI) (Draganov, Stetson, Watson, Billecke, \& La Du, 2000). The signature function of PON1 is to protect cell membrane and circulating lipids against oxidative damage, thereby increasing cytoprotection against apoptosis (Fuhrman, Gantman, \& Aviram, 2010).

Previous studies have indicated that the transfer of systemic PON1 into the ovarian follicular fluid occurs via HDL-mediated transport (Browne et al., 2008; Schneider, Absalon-Medina, Esposito, Correa, \& Butler, 2013). In healthy dominant oestrogenic follicles of cows, PON1 enzyme activity levels range from 30 to $100 \mathrm{U} \mathrm{ml}^{-1}$ (Schneider, Absalon-Medina, et al., 2013). Serum and intrafollicular PON1 enzyme activity as well as ApoAl concentrations have been positively associated with embryo quality and blastomere number in women undergoing in vitro fertilization (IVF) procedures (Browne et al., 2008). Furthermore, PON1 is a negative acute phase protein, and during the post-partum period in dairy cows, its serum activity is reduced in cows diagnosed with metritis and mastitis (Bionaz et al., 2007; Schneider, Corrêa, \& Butler, 2013). Therefore, serum fluctuations of PON1 activity can be reflected in the follicular fluid composition and can compromise oocyte quality and developmental potential after fertilization.

Based on this, the aims of this study were (i) to measure the direct effects of exogenous human recombinant PON1 (rPON1) on bovine oocyte maturation at the molecular level (gene expression) and (ii) to 
measure the carry-over effects of PON1 on pre-implantation embryo development in vitro.

All procedures were approved by the Ethics Committee in Animal Experimentation from Universidade Federal de Pelotas (Protocol 8593). Bovine ovaries were collected from a local abattoir, and cumulus oocyte complexes (COCs) from 2- to 8-mm diameter follicles were aspirated. Only COCs with several layers of cumulus cells and oocytes with a homogenous cytoplasm were selected and randomly divided into four treatment groups ( $n=50$ oocytes/group) supplemented with 0, 0.02, 0.04 and $0.08 \mathrm{mg} \mathrm{ml}^{-1}$ of rPON1 (Chesapeake PERL Inc. Savage, USA) in eight replicates (total of 400 inseminated oocytes/ group).

Oocyte maturation was performed in drops of $400 \mu \mathrm{l}$ using commercial IVM medium (Biotecnologia Animal, Brasilia, Brazil) supplemented with $10 \%$ foetal bovine serum at $39^{\circ} \mathrm{C}$ with $5 \% \mathrm{CO}_{2}$ for $24 \mathrm{hr}$. After maturation, all presumptive matured oocytes were washed and transferred to fresh IVF media ( $400 \mu \mathrm{l}$ drops; Biotecnologia Animal) with $5 \% \mathrm{CO} 2$ in air at $39^{\circ} \mathrm{C}$ for 20 -h co-incubation with purified sperm $\left(1 \times 10^{6}\right.$ sperm $\left.\mathrm{ml}^{-1}\right)$. For these experiments, frozen semen straws from the same ejaculate of a single Bos taurus bull were used. Motile sperm were selected by mini Percoll double density gradient (Nutricell, Campinas, Brazil). After fertilization, putative zygotes were transferred to a manipulation media (Biotecnologia Animal, Brasilia, Brazil) for removal of cumulus cells. Subsequently, denuded zygotes were transferred to commercial in vitro culture (IVC; Biotecnologia Animal) medium supplemented with $5 \%$ foetal bovine serum and placed into $200 \mu \mathrm{l}$ droplets in a culture dish. The dishes were incubated at $39^{\circ} \mathrm{C}$ with $5 \%$ $\mathrm{CO}_{2}, 5 \% \mathrm{O}_{2}$ and $90 \% \mathrm{~N}_{2}$ for 7 days. At D3 and D5, 50\% of serumsupplemented fresh media were replaced. Rates of cleavage and blastocyst development on D2 and D7 were calculated as percentages of the number of inseminated oocytes.

For analysis of PON1 activity, $15 \mu \mathrm{l}$ of the IVM medium was collected at 0 and $24 \mathrm{hr}$ of maturation from each treatment in all eight replicates. PON1 arylesterase activity was quantified by a previously described protocol (Browne et al., 2007) and expressed in $\mathrm{U} \mathrm{ml}^{-1}$. Analysis was performed in a single batch and intra-assay coefficient of variation was $1.2 \%$.

On D7, embryos were transferred to tubes containing $100 \mu$ of Quick-Zol (Ludwig Biotec LTDA, Alvorada, Brazil), homogenized and stored at $-70^{\circ} \mathrm{C}$. Additional $50 \mathrm{COCs} /$ treatment/replicate were collected in three replicates for cumulus and oocyte collection for gene expression. After maturation, COCs were not submitted to IVF and were transferred to hyaluronidase $\left(0.1 \%\right.$ at $39^{\circ} \mathrm{C}$ for $\left.30 \mathrm{~min}\right)$, and oocytes were separated from cumulus cells, transferred into separate microtubes containing $100 \mu$ of Quick-Zol, homogenized and stored at $-70^{\circ} \mathrm{C}$.

RNA was extracted from cumulus cells, oocytes and embryos (RNeasy Mini Kit, Qiagen, Valencia, USA), reverse-transcribed into cDNA (iScript cDNA synthesis kit, Bio-Rad, Hercules, USA) and realtime PCR using the SYBR Green dye (SYBR Green Master Mix, Applied Biosystems, Foster City, USA) was performed to evaluate gene expression. The histone $\mathrm{H} 2 \mathrm{~A}(\mathrm{H} 2 a)$ gene was used as internal control, and target gene indicators of apoptosis, $\mathrm{Bcl} 2$ and $\mathrm{Bax}$, and oxidative stress,
Mnsod, were evaluated (Rho et al., 2007). Relative expression was calculated using the $2^{\Delta \mathrm{Ct}}$ equation.

Statistical analysis was performed using the GLM procedure of SAS (SAS, Cary, NC, USA). A probability of $p<0.05$ was considered statistically significant.

The PON1 activity in the IVM media averaged $2.2 \pm 0.4 ; 15.5 \pm 1.5$; $30.2 \pm 3.0$; and $57.9 \pm 5.0 \mathrm{U} \mathrm{ml}^{-1}$ corresponding to the addition of 0 , $0.02,0.04$ and $0.08 \mathrm{mg} \mathrm{ml}^{-1}$ of rPON1, respectively.

Cleavage rates of zygotes were not different among treatments (Fig. 1, $p=0.38$ ). However, rPON1 supplemented during IVM linearly improved embryo development $(p<0.0001)$, with D7 blastocyst rates of $22.2 \%, 29.4 \%, 32.2 \%$ and $37.0 \%$ corresponding to the addition of $0,0.02,0.04$ and $0.08 \mathrm{mg} \mathrm{ml}^{-1}$ of rPON1, respectively ( $p=0.02$; Fig. 1). Additionally, a positive correlation was found between IVM PON1 arylesterase activity and D7 blastocyst rate $(r=0.35, p=0.04)$.

Supplementing rPON1 during in vitro maturation did not significantly change the level of Mnsod, $\mathrm{Bcl} 2, \mathrm{Bax}$ and $\mathrm{Bcl} 2 \mathrm{Bax}$ ratio in oocytes, cumulus cells and embryos ( $p>0.05$, Table 1 ).
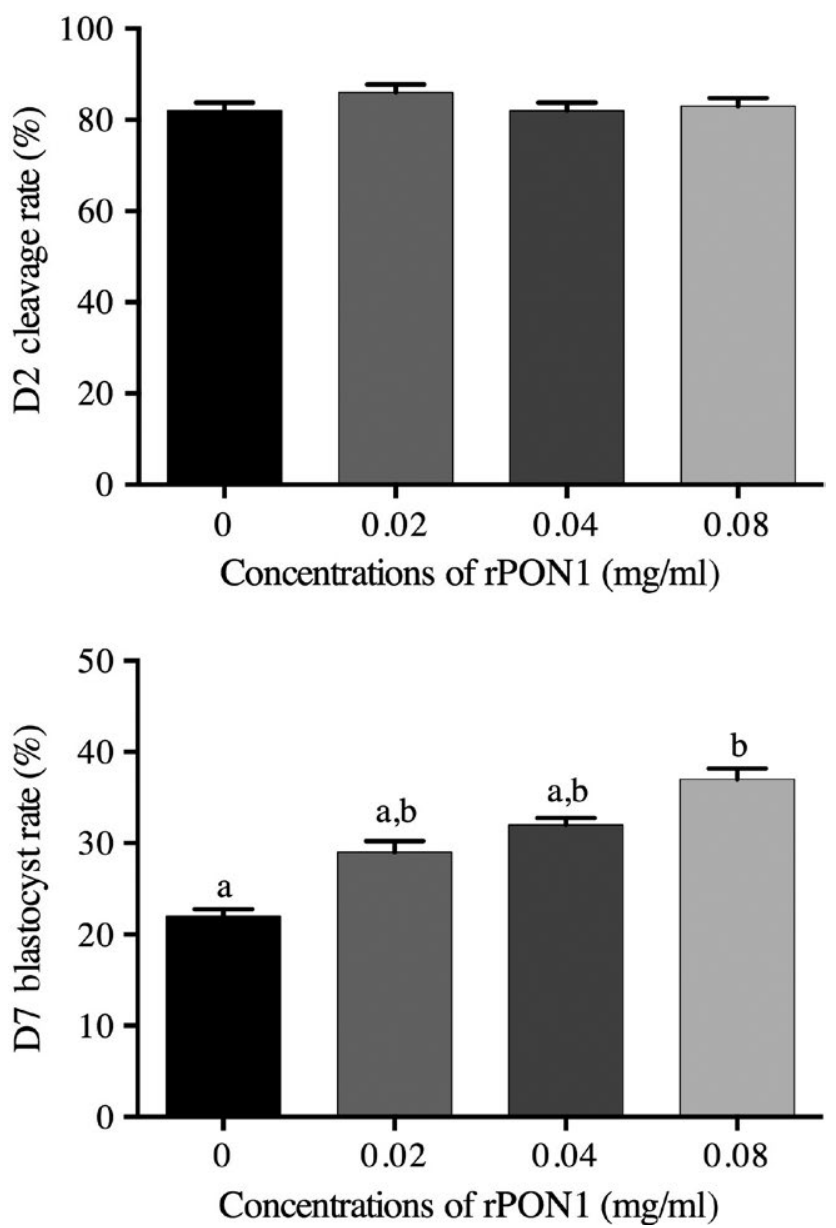

FIGURE 1 Cleavage rate at day 2 (D2) and blastocyst rate at day 7 (D7) following the addition of $0,0.02,0.04$ and $0.08 \mathrm{mg} \mathrm{ml}^{-1}$ of recombinant paraxonase 1 (rPON1) in the maturation media. Data is presented as least square means \pm standard error of the mean. ${ }^{a, b}$ indicate differences at $p<0.05$ 
TABLE 1 Gene expression in oocytes, cumulus cells and embryos after the addition of different levels of rPON1 during oocyte maturation

\begin{tabular}{|c|c|c|c|c|c|c|}
\hline \multirow[b]{2}{*}{ rPON1 (mg $\mu \mathrm{l}^{-1}$ ) } & \multicolumn{2}{|l|}{ Oocytes $^{a}$} & \multicolumn{2}{|c|}{ Cumulus cells $^{a}$} & \multicolumn{2}{|l|}{ Embryos $^{b}$} \\
\hline & $B c l 2: B a x$ & Mnsod & $B c / 2: B a x$ & Mnsod & $B c / 2: B a x$ & Mnsod \\
\hline 0 & $0.62 \pm 0.16$ & $1.00 \pm 0.50$ & $1.20 \pm 0.22$ & $1.00 \pm 1.79$ & $0.50 \pm 0.20$ & $1.00 \pm 0.36$ \\
\hline 0.02 & $0.33 \pm 0.16$ & $0.44 \pm 0.30$ & $1.23 \pm 0.87$ & $0.18 \pm 0.09$ & $0.23 \pm 0.18$ & $1.15 \pm 0.45$ \\
\hline 0.04 & $0.08 \pm 0.03$ & $0.86 \pm 0.77$ & $2.19 \pm 1.11$ & $0.33 \pm 0.16$ & $0.30 \pm 0.16$ & $0.87 \pm 0.28$ \\
\hline 0.08 & $0.12 \pm 0.01$ & $0.59 \pm 0.30$ & $0.73 \pm 0.34$ & $1.23 \pm 1.17$ & $0.54 \pm 0.18$ & $0.43 \pm 0.15$ \\
\hline$p$ value treatment & .68 & .71 & .68 & .71 & .58 & .11 \\
\hline
\end{tabular}

\pm Standard error.

${ }^{a}$ RNA was extracted from 150 COCs in each group (3 replicates).

${ }^{b}$ RNA was extracted from 65, 84, 90 and 97 embryos for groups 0, 0.2, 0.4 and 0.8, respectively (eight replicates).

In the present study, the addition of rPON1 to the IVM media was sufficient to induce enzyme activity similar to what has been observed the follicular fluid of women (Browne et al., 2008) and cows (Schneider, Absalon-Medina, et al., 2013). In addition, the results of our study indicate a dose-dependent effect of rPON1 on COCs during IVM reflected as per improved embryo development by D7, suggesting that PON1 may be beneficial in protecting the oocyte membrane from oxidative and peroxidative damage as demonstrated for other cell types (Fuhrman et al., 2010). A positive correlation between serum and intrafollicular PON1 and ApoAl levels on embryonic development after IVF procedures in women was reported by Browne et al. (2008). Therefore, our study confirms that PON1 alone can exert positive effects on oocyte competence and early embryo development in vitro in cattle.

The ratio between $\mathrm{Bcl}-2$ and $\mathrm{Bax}$ can determine whether a cell will live or die (Rho et al., 2007), while MnSOD is associated with defence against oxidative damage (Lazzari et al., 2011). Previous studies have shown that HDL/PON1 exerts anti-apoptotic and antioxidative effects (Fuhrman et al., 2010); however, no difference was found in the current study.

The working rPON1 protein concentrations used in the current study were based on values observed in the human serum, which is approximately $0.09 \mathrm{mg} \mathrm{ml}^{-1}$ (Mackness et al., 1998). At the same time, average PON1 arylesterase activity is approximately $150 \mathrm{U} \mathrm{ml}^{-1}$ and $90 \mathrm{U} \mathrm{ml}^{-1}$ in human serum and follicular fluid, respectively (Browne et al., 2008). This indicates an estimated 1,600 $\mathrm{U}$ of arylesterase activity per mg of PON1 protein in vivo. In the current study, average PON1 arylesterase activity per mg of rPON1 was half of that, approximately 775, 750 and $725 \mathrm{U}$ for the inclusion of $0.02,0.04$ and $0.08 \mathrm{mg}$ of rPON1. Theoretical values of rPON1 arylesterase activity obtained in vitro are approximately $1250 \mathrm{U} \mathrm{mg}^{-1}$ of protein (Otto et al., 2010) and therefore do not reach the same levels as observed in the human serum.

In conclusion, we were able to reproduce PON1 enzyme activity levels similar to those observed in the follicular fluid of healthy follicles with an intrinsic positive effect reflected as per improved embryo development.

\section{ACKNOWLEDGEMENTS}

This work was supported by Conselho Nacional de Desenvolvimento Científico e Tecnológico (CNPq), Coordenação de Aperfeiçoamento de Pessoal de Nível Superior (CAPES) and Fundação de Amparo a Pesquisa do Estado do Rio Grande do Sul (FAPERGS). The authors also thank to Progen for donating the semen used in the experiments.

\section{CONFLICT OF INTERESTS}

None of the authors of this study has any conflict of interest.

\section{AUTHORSHIP CONTRIBUTIONS}

JJAR contributed on study design, data analysis, experimental work and writing the paper. EMM, FTC, BM and JFS contributed on experimental work. VAAM, WRB and MNC contributed on study design, data analysis and revision of the manuscript. LMCP and AS contributed on experimental work, study design, data analysis and writing the manuscript.

\section{REFERENCES}

Bionaz, M., Trevisi, E., Calamari, L., Librandi, F., Ferrari, A., \& Bertoni, G. (2007). Plasma paraoxonase, health, inflammatory conditions, and liver function in transition dairy cows. Journal of Dairy Science, 90, 1740-1750.

Browne, R. W., Koury, S. T., Marion, S., Wilding, G., Muti, P., \& Trevisan, M. (2007). Accuracy and biological variation of human serum paraoxonase 1 activity and polymorphism (Q192R) by kinetic enzyme assay. Clinical Chemistry, 53, 310-317.

Browne, R. W., Shelly, W. B., Bloom, M. S., Ocque, A. J., Sandler, J. R., Huddleston, H. G., \& Fujimoto, V. Y. (2008). Distributions of high-density lipoprotein particle components in human follicular fluid and sera and their associations with embryo morphology parameters during IVF. Human Reproduction, 23, 1884-1894.

Draganov, D. I., Stetson, P. L., Watson, C. E., Billecke, S. S., \& La Du, B. N. (2000). Rabbit serum paraoxonase 3 (PON3) is a high density lipoprotein-associated lactonase and protects low density lipoprotein against oxidation. Journal of Biological Chemistry, 275, 33435-33442.

Ferré, N., Camps, J., Prats, E., Vilella, E., Paul, A., Figuera, L., \& Joven, J. (2002). Serum paraoxonase activity: A new additional test for the improved evaluation of chronic liver damage. Clinical Chemistry, 48, 261-268. 
Fuhrman, B., Gantman, A., \& Aviram, M. (2010). Paraoxonase 1 (PON1) deficiency in mice is associated with reduced expression of macrophage SR-BI and consequently the loss of HDL cytoprotection against apoptosis. Atherosclerosis, 211, 61-68.

Lazzari, G., Colleoni, S., Duchi, R., Galli, A., Houghton, F. D., \& Galli, C. (2011). Embryonic genotype and inbreeding affect preimplantation development in cattle. Reproduction, 141, 625-632.

Mackness, B., Mackness, M. I., Arrol, S., Turkie, W., Julier, K., Abuasha, B. Miller, J. E., Boulton, A. J., \& Durrington, P. N. (1998). Serum paraoxonase (PON1) 55 and 192 polymorphism and paraoxonase activity and concentration in non-insulin dependent diabetes mellitus. Atherosclerosis, 139, 341-349.

Otto, T. C., Kasten, S. A., Kovaleva, E., Liu, Z., Buchman, G., Tolosa, M., Davis, D., Smith, J. R., Balcerzak, R., Lenz, D. E., \& Cerasoli, D. M. (2010). Purification and characterization of functional human paraoxonase-1 expressed in Trichoplusia ni larvae. Chemico-Biological Interactions, 187, 388-392.

Rho, G.J., S, B., Kim, D.S., Son, W.J., Cho, S.R., Kim, J.G., B, M.K., \& Choe, S.Y. (2007). Influence of in vitro oxygen concentrations on preimplantation embryo development, gene expression and production of Hanwoo calves following embryo transfer. Molecular Reproduction and Development, 74, 486-496.

Schneider, A., Absalon-Medina, V. A., Esposito, G., Correa, M. N., \& Butler, W. R. (2013). Paraoxonase (PON) 1, 2 and 3 expression in granulosa cells and PON1 activity in follicular fluid of dairy cows. Reproduction in Domestic Animals, 48, 989-994.

Schneider, A., Corrêa, M. N., \& Butler, W. R. (2013). Acute phase proteins in Holstein cows diagnosed with uterine infection. Research in Veterinary Science, 95, 269-291. 